ROCZNIKI PEDAGOGICZNE

Tom 11(47), numer specjalny -2019

DOI: http://dx.doi.org/10.18290/rped.2019.11s-30

KS. PAWEŁ WOJTAS

\title{
DUSZPASTERSKA POMOC W SPOŁECZNEJ READAPTACJI OSOBOM PRZEBYWAJĄCYM W JEDNOSTKACH PENITENCJARNYCH
}

Zacznijmy nasze rozważania od analizy źródeł duszpasterstwa więziennego. Popatrzmy na biblijne źródło duszpasterstwa więziennego. W Konkordancji do Pisma Świętego Nowego Testamentu słowo „więzienie” jest użyte 56 razy, a słowo „winny” - 18 razy (Romaniuk, 1985). Od samego początku krzewienia nauki Chrystusa apostołowie oraz kolejni wyznawcy Zbawiciela walczyli o człowieka w najgłębszym rozumieniu wartości humanizmu, a więc antropologii i personalizmu. Za tę postawę oraz nauczanie zapłacili życiem. Historia początków chrześcijaństwa wymienia św. Jakuba Starszego jako pierwszą ofiarę wśród apostołów, zamęczonego w 43 roku, a więc kilkanaście lat po umęczeniu i zmartwychwstaniu Jezusa (Danielou, Marrou, 1984). Od roku 54 w Rzymie panuje cesarz Neron, który w 64 roku podpalił Rzym, a winą za to obarczył chrześcijan. W cyrku rzymskim Koloseum - pisze o tym w swoich rocznikach historyk Publiusz Tacyt, który był jednocześnie świadkiem tych wydarzeń - Neron urządził igrzyska, mordując chrześcijan. Do ofiar tych prześladowań należeli także św. Piotr I papież i św. Paweł Apostoł Narodów. Święci Piotr i Paweł byli najpierw zamknięci w więzieniu sąsiadującym z Koloseum i Forum Romanum, a następnie rozłączeni i każdy z nich zginął w innych okolicznościach. Piotr był Żydem, więc zginął przez ukrzyżowanie na Wzgórzu Watykańskim w 64 roku, Paweł, po przybyciu do Rzymu, był najpierw $\mathrm{w}$ areszcie domowym w latach 61-63, a następnie, po śmierci Piotra, został ponownie uwięziony i skazany na śmierć przez ścięcie mieczem w 67 roku, gdyż z urodzenia był Żydem, ale także obywatelem rzymskim, a Rzymian skazanych na śmierć ścinano mieczem. Przykład pierwszych ludzi Kościoła

Ks. dr Pawę Wojtas - Wyższa Szkoła Bezpieczeństwa i Ochrony im. Marszałka Józefa Piłsudskiego w Warszawie, ul. Zakroczymska 13, 00-225 Warszawa; e-mail: wojtaspawel@wp.pl 
uczy nas, jak od początku w chrześcijaństwie walczono o człowieka w pełnym jego rozumieniu i rozwoju antropologiczno-personalistycznym.

Po wspomnieniu początku więziennych problemów chrześcijaństwa, z racji 100-lecia polskiego więziennictwa po odzyskaniu przez Polskę niepodległości, przejdziemy do krótkiej historii i zadań, jakie podejmuje Kościół w Polsce w kwestii więziennictwa.

W okresie powojennym duszpasterstwo więzienne w Polsce było przez władze komunistyczne niemal całkowicie wyeliminowane. Jedynie w sytuacji przed wykonaniem wyroku śmierci lub w przypadku ciężkiej choroby, w następstwie czego mógł nastąpić zgon skazanego, dopuszczano kapelana wojskowego lub proboszcza miejscowej parafii do więźnia (Pierzchała, 2013), i to najczęściej wtedy, gdy prosił sam zainteresowany. Dopiero sytuacja społeczno-polityczna związana z powstaniem ruchu „Solidarność” zaowocowała radykalną zmianą. W Zarządzeniu Ministra Sprawiedliwości z dnia 17.09.1981 r. zezwolono, aby wyznaczeni przez biskupów diecezjalnych księża mogli wchodzić do zakładów karnych z posługą duszpasterską. W latach 1981-1989 pracę kapelanów w pewnym stopniu „reglamentowano”, zezwalając jedynie na odprawianie Mszy św. w zakładach karnych, a areszty śledcze nadal pozostawały bez opieki duszpasterskiej.

$\mathrm{Na}$ początku lat dziewięćdziesiątych, wraz ze zmianą kierownictwa Centralnego Zarządu Zakładów Karnych, nastąpiła też pewna zmiana warunków sprawowania opieki duszpasterskiej nad osadzonymi. Dyrektor Paweł Moczydłowski, piastujący te funkcję od 10 kwietnia 1990 r., przyczynił się do tego, że zaczęto coraz częściej dostrzegać pozytywną rolę obecności religii w więzieniach. Podobnie jak w okresie międzywojennym przyjęto, że posługi religijne stanowią może nie tyle jedną z form działalności resocjalizacyjnej, ale zapewne są z nią głęboko powiązane. Kapelan bowiem, poprzez swą posługę na terenie jednostki penitencjarnej, może realizować dwie funkcje: udzielać posług religijnych sensu stricto, a także prowadzić działalność duszpasterską zmierzającą do takiego ukształtowania skazanych, aby na co dzień postępowali zgodnie z normami moralności chrześcijańskiej i krytycznie oceniali swoje dotychczasowe zachowanie.

Kolejnym etapem kształtowania się duszpasterstwa penitencjarnego w nowej rzeczywistości polityczno-społecznej było mianowanie ks. Jana Sikorskiego - Krajowego Duszpasterza Więziennego - na stanowisko Naczelnego Kapelana Więziennictwa Rzeczpospolitej Polskiej. Dokonało się to na mocy dekretu ministra sprawiedliwości z dnia 1 października 1990 roku. Decyzja ta umocniła obecność Kościoła za więziennym murem i pozwoliła także na wejście Polski w skład międzynarodowych organizacji penitencjarnych. 
Problematyka obecności kapelana w zakładach karnych i aresztach śledczych została także podjęta w Konkordacie z dnia 28 lipca 1993 r. W tym dokumencie - zarówno dla Stolicy Apostolskiej, jak i Rzeczypospolitej Polskiej - nadrzędnymi wartościami były godność osoby ludzkiej i jej prawa. Nie mogło też zabraknąć tak istotnej kwestii, jak prawo osób przebywających w zakładach karnych do opieki duszpasterskiej. Artykuł 17 tej dwustronnej umowy stwierdzał, że Państwo zapewnia warunki do wykonywania praktyk religijnych i korzystania z posług religijnych osobom przebywającym w zakładach penitencjarnych, wychowawczych i resocjalizacyjnych. Na Rzeczypospolitej Polskiej spoczywa obowiązek stworzenia w wymienionych zakładach zamkniętych takich warunków, które umożliwiłyby realizację zapisów konkordatowych.

Konstytucja Rzeczypospolitej Polskiej to kolejny dokument, o którym należy wspomnieć przy omawianiu duszpasterstwa penitencjarnego. Każdy człowiek, także przebywający w jednostce penitencjarnej, ma prawo do wolności sumienia i wyznania, którego istotnym elementem jest prawo do wykonywania praktyk religijnych, co wszystkim obywatelom naszego kraju gwarantuje właśnie przepis art. 53 Konstytucji $\mathrm{RP}^{1}$.

Prawo do wykonywania praktyk religijnych wynika również z przepisów prawa międzynarodowego. Powszechna Deklaracja Praw Człowieka z 10 grudnia 1948 r. w art. 18 głosi:

Każdy człowiek ma prawo do wolności myśli, sumienia i religii, prawo to prezentuje swobodę zmiany religii lub wiary, jak również swobodę do samodzielnego lub wspólnego z innymi, publicznego lub prywatnego manifestowania swojej wiary lub religii w nauczaniu, praktykach, modlitwie i obyczajach.

Bezwzględnym gwarantem wolności sumienia i religii pozostaje niezmiernie Kościół katolicki.

Na podstawie regulaminowych zapisów każdy dyrektor ustala odrębny dla danego zakładu karnego porządek wewnętrzny. Określa w nim harmonogram funkcjonowania jednostki oraz ustala terminy i miejsce odprawiania nabożeństw oraz korzystania z posług religijnych. Dyrektor może jednak wstrzymać lub

\footnotetext{
${ }^{1} \mathrm{~W}$ paragrafie pierwszym tego artykułu możemy przeczytać: „Każdemu zapewnia się wolność sumienia i religii”, natomiast paragraf drugi tego samego artykułu stanowi, że „Wolność religii obejmuje wolność wyznania lub przyjmowania religii według własnego wyboru oraz uzewnętrzniania indywidualnie lub z innymi, publicznie lub prywatnie, swojej religii przez uprawianie kultu, modlitwę, uczestniczenie w obrzędach, praktykowanie i nauczanie. Wolność religii obejmuje także posiadanie świątyń i innych miejsc kultu w zależności od potrzeb ludzi wierzących oraz prawo do korzystania z pomocy religijnej, tam gdzie się znajdują".
} 
ograniczyć odprawianie nabożeństw i innych praktyk religijnych. Ograniczenia te mogą wystąpić tylko okresowo i w uzasadnionych okolicznościach.

Skazany ma prawo wykonywać praktyki religijne w taki sposób, by nie zakłócać spokoju i ustalonego w zakładach porządku. Może mieć w celi przedmioty kultu religijnego. Ma prawo słuchać nabożeństw transmitowanych przez środki masowego przekazu, a także uczestniczyć w nabożeństwach odprawianych w zakładzie. Może też korzystać z posług religijnych kapelana lub innego kanonicznie uprawnionego przedstawiciela Kościoła lub wyznania, który może odwiedzać skazanych w celach i innych pomieszczeniach. Działalność wyznaczonego kapelana albo uprawnionego przedstawiciela innego wyznania wymaga zgody dyrektora w zakresie form pracy duszpasterskiej, jednak nie można jej zakazać. Zgodnie z Europejskimi Regułami Więziennymi w żywieniu skazanych uwzględnia się wymogi kulturowe i religijne, oczywiście w miarę możliwości. Podobne zapisy zawiera regulamin tymczasowego aresztowania, jednak zbiorowe praktyki religijne ograniczają wymogi postępowania karnego. Decydujący głos w tej sprawie należy do organu dysponującego, który może zabronić wspólnikom udziału w zbiorowych nabożeństwach, a jedynie zgodzić się na indywidualny kontakt $\mathrm{z}$ osobą duchową.

Obowiązująca od września 2001 roku ustawa o Służbie Więziennej wymienia zapewnienie prawa skazanych i tymczasowo aresztowanych do opieki religijnej. W rejestrze organizacji, z którymi służba powinna współpracować w wykonywaniu kary, wymienia się Kościoły i związki wyznaniowe. Jednym z zadań dyrektora zakładu karnego lub aresztu śledczego jest współdziałanie w realizacji zadań z Kościołami i związkami wyznaniowymi lub osobami godnymi zaufania. Zgodnie z art. 102 pkt 3 Kodeksu karnego wykonawczego skazany ma prawo do korzystania $\mathrm{z}$ wolności religijnej.

W niniejszym artykule analizujemy sens duszpasterstwa więziennego $\mathrm{w}$ istotnym wymiarze, czyli biblijno-teologiczno-pastoralne uwarunkowania w pracy z osobami izolowanymi karnie, w ramach podstawy, jaką daje klasyczna filozofia realna (egzystencjalna). Jest to personalistyczne rozumienie duszpasterstwa więziennego.

Chrześcijańskie duszpasterstwo więzienne, ze swej istoty, opiera się na przekazie biblijnym oraz tradycji Kościoła. Biblijny autor natchniony - jak mówimy o ludzkim przekazie permanentnych Bożych wartości Starego i Nowego Testamentu - z Księgi Mądrości uprzytamnia czytelnikowi pozycję osoby ludzkiej w rzeczywistości wszechświata. Oto - z jednej strony - Kreator istnienia umieścił osobę ludzką jako pierwszą w wolitywno-intelektualnym porządku zarządzania wszechświatem, od której będzie zależeć powodzenie realizacji istnienia, z drugiej strony - tak umieszczony człowiek w porządku istnienia 
powinien pamiętać, kto jest jego twórcą, czyli źródło własnej egzystencji, w którym zawsze czuje się naturalnie i bezpiecznie (por. „Boże przodków i Panie miłosierdzia, któryś wszystko uczynił swoim słowem i w Mądrości swojej stworzyłeś człowieka, by panował nad stworzeniami, co przez Ciebie się stały, by władał światem w świętości i sprawiedliwości i w prawości serca sądy sprawował - dajże mi Mądrość, co dzieli tron z Tobą [...]. Bom sługa Twój, [...] człowiek niemocny i krótkowieczny. Choćby zresztą był ktoś doskonały między ludźmi, jeśli mu braknie mądrości od Ciebie - za nic będzie poczytany" (Mdr 9, 1-7).

Działania współczesnego człowieka dotyczą wyborów w podejmowanych decyzjach: czy postawić siebie i swoje ludzkie prawa w miejsce Kreatora, czy pokornie trwać w porządku kreacji rzeczywistości, która poprzez sam fakt porządku we wszelkich formach istnienia wskazuje na jego Twórcę.

Potrzeba, tworzenie i interpretacja praw ludzkich ciągle rozbija się o uwzględnianie bądź oddalanie prawa nadnaturalnego - jako dotyczącego lub niemającego sensu dla ludzkich postanowień jurydycznych. Duszpasterze więzienni, respektując prawo przyrodzone, jednocześnie odwołują się, w swym kontakcie $\mathrm{z}$ osadzonymi, do naturalnie odczuwanej przez człowieka potrzeby prawa nadprzyrodzonego, które konstruuje istotę poczucia człowieczeństwa.

Zachowania patologiczne (Pierzchała, Cekiera, 2008; 2009) mają wielorakie konsekwencje, ale pierwotnie wywodzą się z negatywnych źródeł moralno-etycznych. Jeśli człowiek dewaluuje duchowe wartości permanentne dla rozwoju i godności własnej osobowości, to skutki tego odczuwa się w szeroko rozumianych relacjach interpersonalnych. Człowiek jako struktura duchowo-fizyczna, zatracając niewymierny świat wartości duchowych, mimo iż współcześnie dochodzi do coraz lepszej techniki inteligentnej, zatraca tym samym świat ilościowo-jakościowych wartości wymiernych (mierzalnych), ponieważ zła kondycja moralno-etyczna jest w stanie zniszczyć mozolnie rozszyfrowywany i budowany świat materii. Stąd analiza jakości prawa, intencji wyznaczających kierunki jego rozwoju, zachowań ludzkich wywołujących konflikt z prawem i dróg ich eliminacji nie może być kompletna bez filozoficznych i moralno-etycznych analiz o duchowej osobowości i godności człowieka.

Zwróćmy uwagę na istotny związek następczy: w zależności jak filozoficznie rozumiemy i interpretujemy człowieka i ludzkie relacje interpersonalne, tak konstruujemy prawo, w którym, w zależności od sytuacji kulturowej lub społeczno-politycznej, kładzie się nacisk na możliwości naprawy i rozwoju osobowości, stawiając na naprawczość w systemach legislacyjnych lub wzmacnia się funkcję punitywną prawa.

Współcześnie nastąpiła moda na myślenie relatywistyczne, na relatywizowanie wszelkich wartości, w tym samego człowieka, a w następstwie wszelkich 
procesów, w których uczestniczy osoba ludzka, także społeczności. Inaczej rozumie się i ocenia wartość bytu ludzkiego, nie traktując go jako naturalną, podstawową, permanentną wartość, a inaczej definiuje się osobę ludzką, jej wartość, godność oraz pojęcie sensu życia, które jest źródłem pracy z człowiekiem, także w warunkach izolacji więziennej, w następstwie klasycznej filozofii realnej (egzystencjalnej).

W relatywizmie (łac. relativus - względny) wartość poznania ludzkiego jest względna i subiektywna dlatego, że nie da się osiągnąć prawdy (sceptycyzm) bądź dlatego, że nie można dotrzeć do istoty rzeczy (krytycyzm). Relatywizm odrzuca możliwość obiektywnego kryterium prawdy, uzależniając jej ujęcie od konstytucji umysłu i narządów zmysłowych poszczególnych podmiotów poznających, od środowiska społecznego, warunków historycznych (konwencjonalizm, pragmatyzm). Relatywizm wiąże się z subiektywizmem, psychologizmem, historyzmem. W relatywizmie wartości etyczne, dyrektywy i oceny moralne mają charakter względny, zmieniają się w różnych czasach i społeczeństwach, przy czym owe zmiany nie składają się na proces, który można by uznać za postęp. Relatywizm moralny wiąże się z twierdzeniem, że - po pierwsze - zachodzą różnice w poglądach na moralność ze względu na to, że co dla jednych jest dobre, dla innych jest złe; po drugie - oceny moralne są zmienne w zależności od warunków, w jakich znajduje się osoba wypowiadająca oceny, i od jej subiektywnego nastawienia; po trzecie - nieintrospekcyjne oceny sprzeczne mogą być jednocześnie i pod tym samym względem prawdziwe lub fałszywe (Podsiad, Więckowski, 1983, s. 336 n.).

W myśl realnej (egzystencjalnej) filozofii klasycznej rozważamy w pismach i katechezach fakt życia ludzkiego w ogólności i szczególności. W ogólności analizujemy uwarunkowania życia ludzkiego wypływające z istoty ludzkiego bytu bez względu na warunki, w jakich osoba żyje. Poznawczo dochodzimy do czegoś, co jest istotą sensu życia w ogóle i co je uniesprzecznia. W szczególności analizujemy cały kontekst życia jednostki, czyniący to życie konkretnym, i rozpatrujemy z pozycji uprzednio przyjętego pojęcia sensu i uniesprzecznienia.

Życie duchowe człowieka to zespół czynności, które bezpośrednio, co do natury i genezy, wiążą się z człowiekiem jako osobą, ludzkim ,ja”. Działania świadome, w tym najistotniejsze, jak miłość, są autorstwa człowieka i nie da się ich sprowadzić do „układu zamkniętego” w sferze procesów biologiczno-fizjologicznych lub psychicznych w postaci przeżyć. Życie ludzkie to ciągły proces „uzupełniania się” osoby, dynamiczny, czyniący człowieka „otwartym” do śmierci. Świadomość, wolność to elementy konstytutywne życia ludzkiego, bo wypływają z ,ja” osobowego. Osobowość ludzka to kształtujące się „ja” osobowe od poczęcia w świadomych aktach płynących z wewnątrz i zewnątrz. 
Nie może być osobowości w oderwaniu od osoby. Podmiot życia daje podstawy, że jego życie, obdarzone świadomością i wolnością, ma charakter zindywidualizowany, tj. uspecyfikowany przez podmiot na miarę jego samego. Świadomość to poczucie przeżywania zachodzących osobowych aktów w postaci działania czegoś, dostosowania czegoś, także rozumienie i uzasadnienie tych aktów. Wolność to niezdeterminowanie zachowania przez czynniki zewnętrzne, któremu towarzyszy możliwość wyboru zachowań. Człowiek realizuje się w pewnej czasoprzestrzeni, nie żyje w „czystym” i „pustym” czasie, ale wypełnionym treściami. Życie ludzkie jest więc kompleksem działań (Morawiec, 2000).

Czynnikiem uzasadniającym pojawienie się działania w bycie jest inklinacja skłaniająca podmiot do działania. W inklinacji przejawia się dążenie do tego, co dla bytu jako podmiotu działania jest potrzebne, by istniał i rozwijał się. Przedmiot takiej inklinacji to dobro. Inklinacja do doskonalenia jest konsekwencją natury osoby ludzkiej. Człowiek w wymiarze osobowym jest (jak w wymiarze natury) bytem aktualno-możnościowym, naturalnie otwartym na stawanie się. Aspekt możnościowy to zespół dyspozycji czekających na realizację, to ontyczne ukierunkowanie na to, co dla człowieka dobre. Treści naturalne, czyli to, co wynika z natury człowieka jako aspekt potencjalny i integralny zarazem, są dobre dla człowieka. Tak pojęte dobro jest dobrem ontycznym, dyktowanym dynamiczną strukturą bytu osoby ludzkiej. Realizacja tak pojętego dobra stanowi naturalny ontyczny, czyli istnieniowy sens osobowego życia (trwania) człowieka. Jest to norma absolutna ludzkiej aktywności, która wyznacza porządek powinności (Morawiec, 2000).

Są dwa porządki realizacji ludzkiego życia: porządek tego, co jest, i porządek tego, co być powinno. Porządek ,jest” wyznacza porządek tego, „,o być powinno”. Porządek ,jest” to świat wartości osobowych konstytuujących człowieka jako osobę w jej naturze, czyli jest kryterium dobra i zła jako właściwości ludzkiego działania. Porządek tego, co być powinno, wyznacza, kim człowiek być powinien. Zatem życie ludzkie jest sensowne, gdy osadza się w najgłębszych warstwach człowieka, a więc na tym, co konstytuuje naturę osoby ludzkiej jako osoby. Nie na powierzchni subiektywno-emocjonalnej. Decyzja ludzka, która ma realizować sens życia, występuje, realizując pierwszy porządek na rzecz drugiego. Człowiek może świadomie i wolnie (rozumnie) ustosunkowywać się do tych porządków. Akceptacja realizacji powyższych dwóch porządków egzystencji stanowi sensowność ludzkiego życia. Warto przyswoić sobie klasyczne, realistyczne myślenie o sensie ludzkiego życia, szczególnie współcześnie, gdy różne, podpowiadane tak medialnie, „filozofie" relatywistycznie indoktrynują człowieka oraz całe społeczeństwa na temat tego, co jest i nie jest sensem życia (Morawiec, 2000). W powyższy 
sposób zanalizowaliśmy, jak filozofia pozostaje fundamentalna dla rozumienia antropologii, a w następstwie dla ludzkich czynów, które mogą rozwijać osobowość lub zatracać w patologii niejednokrotnie kończącej się izolacją więzienną.

Nie rodzimy się z zakodowaną agresją czy genetycznym uwarunkowaniem do działań przestępczych. To świat ludzi dorosłych przekazuje młodym ułomne postawy, niwelujące obiektywizm zasad moralnych, jak współczesne popularyzowanie postępowania o charakterze relatywizmu moralnego i etycznego. Uznanie przez człowieka, że jego istnienie i osobowość same w sobie stanowią fundamentalne kryterium ustanawiania wartości i zasad, kreują relatywistyczne rozumienie życia i wynikających z niego relacji. Tymczasem do właściwej definicji i oceny rzeczywistości konieczna jest akceptacja przez człowieka jego rzeczywistej pozycji egzystencjalnej, polegającej na uznaniu prawdy o uzależnieniu osoby ludzkiej od aktu stwórczego, istniejącego poza człowiekiem. Ludzkość jedynie potrafi przekazywać życie, a nie je tworzyć (Wojtas, 2007).

Przypomnijmy zatem, czym jest religia, aby dokonać choćby symbolicznej analizy prac podejmowanych obecnie w ramach duszpasterstwa więziennego.

Faktem religijnym w pierwotnym, podstawowym znaczeniu jest samo odniesienie, skierowanie człowieka do rzeczywistości transcendentnej. Dane jest ono zalążkowo w pierwotnym doświadczeniu człowieka siebie jako osoby, własnej ograniczoności i potrzeby transcendencji, w sposób bardziej rozwinięty w przeżyciu religijnym, a ujawnia się zasadniczo w specjalnym zachowaniu człowieka, wyrażonym w aktach religijnych (Zdybicka, 1977, s. 120).

Definicja ta ukazuje dwa obszary rozpoznania religijnego w człowieku. Pierwszy, pierwotny, to wewnętrzne odczucie własnej ograniczoności egzystencjalnej, co wiąże się z potrzebą odnalezienia, umiejscowienia siebie w obszarze transcendencji. Drugi obszar, rozwijany (wtórny), to ten, w którym następuje świadomy, dobrowolny rozwój osobistego dialogowania człowieka z Bogiem (transcendencją). Zatem fundamentalna praca duszpasterska $z$ osobami odizolowanymi w zakładach penitencjarnych polega na pomocy w odkrywaniu przez nich potrzeby, a następnie - świadomym kształtowaniu postawy religijnej, która z kolei ma kształtować właściwą postawę ludzką. Zauważmy, że powyższa definicja przedstawia fakt religijny nie jako coś, co przychodzi do człowieka z zewnątrz, ale jako rzeczywistość dialogowania z Bogiem, która wyrasta z natury ludzkiej. Religijność można zagłuszać w sobie różnymi fenomenami zewnętrznymi, stanami emocjonalnymi, ale religia sama w sobie 
fundamentalnie się wiąże z wnętrzem człowieka, z faktem bycia osobą. Są to zasadnicze przesłanki odkrywania w sobie potrzeby i możliwości religijnego życia, które ma się przekładać na wartościowe, moralne życie osadzonego (Wojtas, 2006; Wojtas, Pierzchała, 2015).

Upraszczając analizy, których należałoby dokonać na podstawie definicji faktu religijnego, można uznać, że praca duszpasterska z osobami skonfliktowanymi z prawem, moralnością, społeczeństwem i samym sobą polega na: (1) przywracaniu ich najpierw samym sobie (na zaakceptowaniu własnej sytuacji bytowej i przyjęciu prawdy o sobie samym); (2) odnajdywaniu moralności na podstawie chrześcijańskiej kodyfikacji wartości i powinności; (3) zaakceptowaniu konieczności uregulowania powinności prawnych (zrozumieniu obowiązku odbycia kary, wydobywanie sensu z faktu ukarania); (4) uczeniu potrzeby (uwrażliwianiu) zadośćuczynienia ofiarom lub ich najbliższym i społeczeństwu. Osiągnięciu tych celów służy publiczny (społeczny) kult religijny, ponieważ człowiek jest istotą społeczną i potrzebuje w społeczności (częściowo wobec społeczności) wyrażać przeżycia wewnętrzne. Liturgiczny kult religijny wyraża najgłębsze treści religijne, etyczno-moralne i ogólnoludzkie, uzmysławia osobie przeżywającej kontakt $\mathrm{z}$ transcendencją, kim jest człowiek jako żyjący byt. Dlatego sprawowanie liturgii jest takie ważne (Wojtas, 2007). Przedstawione powyżej rozważania zwracają uwagę na konieczność ujmowania człowieka, w specyficznej sytuacji izolacyjnej, z jak najgłębszym poszanowaniem wartości płynących z chrześcijańskiego zrozumienia antropologii i personalizmu.

Opierając się na powyższych analizach trzeba zaznaczyć, że od jesieni 1989 roku zaczęto regularnie rozwijać różne, adekwatne formy duszpasterstwa więziennego. Od tego czasu każde więzienie i areszt śledczy miały już swoich kapelanów. Panowały nadal obostrzenia, szczególnie w aresztach śledczych, jednakże kontakt kapelana z osadzonymi był możliwy. Po 1989 roku zaczęła się stopniowa normalizacja i organizacja pracy duszpasterstwa więziennego. Konferencja Episkopatu Polski mianowała Krajowego Duszpasterza Więziennictwa (w nomenklaturze państwowej Naczelnego Kapelana Więziennictwa RP), prawodawstwo państwowe zmieniło przepisy w stosunku do tymczasowo aresztowanych, zezwalając im z samego faktu pobytu w izolacji na możliwość uczestniczenia w praktykach religijnych (początkowo każdy osadzony $\mathrm{W}$ areszcie musiał mieć osobistą zgodę prokuratora na uczestnictwo w praktykowaniu religijnym), zaczęto organizować kaplice na sprawowanie kultu. W adaptację pomieszczeń na kaplice włączali się swoją pracą więźniowie, co wpływało bardzo pozytywnie na eliminację czasami napiętej atmosfery między personelem więziennym a osadzonymi. Stopniowo księża kapelani 
rozpoczęli prowadzenie rozmów indywidualnych z więźniami, przygotowaniem ich do sakramentów świętych, np. chrztu św. i bierzmowania. Coraz częściej zakłady karne i areszty śledcze były odwiedzane przez księży biskupów przy okazji bierzmowania czy wizytacji parafii. Ksiądz Sikorski, a wraz z nim ks. Paweł Wojtas - jako asystent naczelnego kapelana, inicjowali działania, które stopniowo doprowadzały do usystematyzowanych standardów tej pracy. Chodzi o doroczne rekolekcje i konferencje duszpasterzy więziennictwa, doroczne spotkania kapelanów diecezjalnych Służby Więziennej, organizacje pracy świeckich wolontariuszy więziennictwa i doroczną ich programową konferencję oraz doroczną pielgrzymkę funkcjonariuszy na Jasną Górę. Ze zjazdów kapelańskich i osób świeckich wydawano „Materiały Seminaryjne” programujące naszą pracę.

W październiku 2001 roku ks. Sikorski przeszedł na emeryturę, po dwudziestu latach pracy, począwszy od stanu wojennego w 1981 roku. Także w październiku 2001 roku Konferencja Episkopatu Polski mianowała nowego Krajowego Duszpasterza Więziennictwa - ks. Pawła Wojtasa, długoletniego kapelana AŚ Warszawa-Białołęka i jednocześnie długoletniego współpracownika ks. Sikorskiego.

Z pracy księży kapelanów więziennictwa - etatowych czy zatrudnionych na cząstkach etatów - wynika, że posiadanie etatu korzystnie wpływa na jakość pracy księdza. Ksiądz jest wtedy cząstką załogi, ma prawo swobodnego wstępu do każdego miejsca w jednostce, w ramach potrzeby działań. Jest systematyczna Eucharystia, przygotowanie do innych sakramentów, koordynacja pracy świeckich wolontariuszy, odbywa się znacznie więcej rozmów indywidualnych z osadzonymi. Nie chodzi więc o obligatoryjne rozdawanie etatów księżom, ale racjonalne uzgodnienia dotyczące czasowych możliwości pracy kapelana i możliwości zakładu, który zatrudniając kapłana, może więcej świadczyć pomocy w realizacji misji duszpasterskiej. Dzięki księżom etatowym mamy w polskich zakładach kilka programów resocjalizacyjnych, które znajdują uznanie u władz więziennych ${ }^{2}$.

\footnotetext{
${ }^{2}$ Pomysłów na realizację potrzeb działań nie brakuje. Za pośrednictwem mediów, internetu informujemy społeczeństwo, a także zapraszamy do dialogu ubogacającego możliwości pracy. Kontakt medialny z kapelanami więziennictwa, możliwości zadawania im pytań i dyskusji o różnych formach działań pastoralnych pomagają społeczeństwu zrozumieć sposoby wykonywania kary pozbawienia wolności. Pomocne w tych działaniach są „Materiały Seminaryjne Duszpasterstwa Więziennego”, w których publikujemy rekolekcje kapelańskie, referaty oraz dyskusje. Z perspektywy lat widać, że są to materiały wartościowe, ponieważ omawiają rzeczywistą problematykę pastoralną.
} 
Jan Paweł II, pielgrzymując duszpastersko po Ojczyźnie, dnia 7 czerwca 1991 roku był w zakładzie karnym w Płocku (Pierzchała, 2015a). Osadzony, Przemysław, z zakładu karnego w Płocku napisał o sobie dzięki pobytowi Jana Pawła II w tym zakładzie:

Wiele razy dane mi było zarówno słuchać, jak i oglądać Jana Pawła II w różnych, częstokroć nieznanych mi zakątkach świata, i za każdym razem zdumiewał mnie wpływ, jaki wywierał na zgromadzonych wokół siebie ludzi. Nie pojmowałem tego aż do pamiętnego dnia, w którym przyjechał do nas, do oczekujących Go więźniów i pracowników Zakładu Karnego. Doskonale pamiętam chwilę, gdy Ojciec Święty bez wahania wszedł wprost w zgromadzony na dziedzińcu więziennym tłum; znajdowałem się w gronie tych szczęśliwców, którym dane było znaleźć się najbliżej. Pamiętam zbliżającą się postać, pamiętam twarz, na której malowało się coś z najgłębszej ojcowskiej troski, a jednocześnie wrażającą jakiś nieokreślony smutek - była to chwila, w której nie istniał dla mnie nikt inny: nie było innych więźniów, nie było strażników ani krat - sądzę, że podobne odczucie miał wówczas każdy z obecnych. Nie było wątpliwości i niepewności, nagle bowiem moim jedynym pragnieniem stało się móc choć przez sekundę znaleźć się jeszcze bliżej, tak blisko, by nie dzieliła mnie od Ojca Świętego żadna przestrzeń. A potem, gdy z wilgotnymi oczyma, ustami duszy, dziękowałem za łaskę ucałowania pierścienia Rybaka, zrozumiałem wszystko. Siła osobowości Papieża, Jego autorytet i aura, jaką roztaczał, sprawiły, że już wiedziałem, już znałem odpowiedź. Była to jakaś nieodparta moc, jakiś niesłychany spokój i miłość emanujące z całej postaci Jana Pawła II. Pamiętam, śpiewaliśmy wówczas pieśń, której zwrotka rozpoczynała się słowami: „Gdy w życiu tak pełnym rozczarowań, o losu kamienie potknę się..." - wspominam ją dziś, bo w tamtej pamiętnej chwili otrzymałem wiarę i siłę: wiarę, że można iść przez życie bez potknięć, i siłę, by móc tego dokonać. I choć w ciągu minionych dziesięciu lat nie udało mi się wielu z owych potknięć uniknąć, nadal mam w sobie wiarę, że można, że jeszcze mogę żyć z godnością, jak człowiek, nie jak zwierzę egzystujące na śmietniskach ludzkiego życia - odzyskałem bowiem szacunek dla samego siebie. I gdybym teraz, po dziesięciu latach, miał jeszcze szansę ujrzeć Ojca Świętego, gdybym mógł do Niego przemówić, podziękowałbym Mu za tę krótką chwilę, w której był przy mnie, chwilę, która na zawsze mnie odmieniła i sprawiła, że patrzę w przyszłość bez lęku. Dziękuję Ci, Ojcze Święty. Dziękuję z całego serca.

Przepięknym przykładem duszpasterstwa więziennego jest to, jak więźniowie pomagają w pielgrzymce niepełnosprawnych na Jasną Górę na uroczystości 15 sierpnia. Aby dać przykład praktycznej działalności polskiego duszpasterstwa więziennego zaprezentuję obszerne wyjątki z tekstów napisanych przez 
samych więźniów na temat tego, co dało im korzystanie z duszpasterstwa więziennego. W roku milenijnym wystąpiliśmy z unikalną na skalę światową propozycją zorganizowania pieszej pielgrzymki dla skazanych na Jasną Górę w Częstochowie. Wszyscy w Polsce wiedzą, co to jest piesza pielgrzymka do Częstochowy i jak może ona posłużyć do pracy naprawczej nad człowiekiem. Chodziło o to, aby trud pieszego pielgrzymowania był dla osadzonego jakąś nauką. Pielgrzymowanie ma charakter wybitnie społeczny, a więc włączanie się w społeczny wysiłek może dać jakieś rezultaty - zmianę myślenia i postępowania na bardziej prospołeczne. Zaproponowaliśmy (po odpowiednim przygotowaniu i zgodzie administracji więziennej), aby kilku chętnych więźniów wzięło udział w pieszej pielgrzymce niepełnosprawnych na Jasną Górę. Po dwóch więźniów zostało przydzielonych do jednego wózka inwalidzkiego i miało za zadanie ten wózek pchać, wykonywać wszystkie prace przy osobie sparaliżowanej, a na koniec dnia przygotować wózek do kolejnego odcinka trasy. Dla więźniów grypsujących wykonywanie podstawowych czynności obsługujących osobę chorą (mam na myśli pomoc w toalecie czy umycie chorego) jest czymś nie do pomyślenia. Podczas pielgrzymki te bariery zostały przełamane. Interesowało nas źródło owej przemiany. W wielkim skrócie mogę powiedzieć, że ta przemiana osobowościowa w kierunku usłużenia osobie sparaliżowanej nazywa się w języku religii nawróceniem, czyli zmianą przyjmowanych wartości, zmianą motywacji postępowań i zachowań. Źródłem i sensem chęci zmiany pozostają wartości najgłębsze, transcendentne. Jeden z więźniów powiedział w podobnych słowach: chciałem pomóc, bo ja jestem zdrowy, silny, Bóg mnie obdarzył zdrowiem i siłą, a ja, lekceważąc te Boże dary, innym czyniłem źle, a przede mną była osoba całkowicie bezbronna, niewinna, która nikomu nie mogła wyrządzić szkód, i tak niewinnie cierpiąca (por. szerzej: Pierzchała, 2015b; 2016; 2017).

Poszukując potwierdzeń i wskazówek na przyszłość co do trafności działań duszpasterskich w więzieniach, zazwyczaj prosimy osadzonych o ich anonimowe wypowiedzi ankietowe lub świadectwa na temat konkretnych przedsięwzięć. Oto obszerny fragment świadectwa skazanego, biorącego udział w pieszej pielgrzymce na Jasna Górę w Częstochowie, które zatytułował „Zarazić się dobrem" (już sam tytuł sformułowany przez więźnia daje do myślenia).

Zostałem skazany prawomocnym wyrokiem na 11 lat pozbawienia wolności za zabójstwo człowieka. Przebywam w zakładach karnych od ośmiu lat, mam natomiast niespełna 32 lata, ale dopiero około pięciu lat temu zacząłem wspaniałą podróż, cudowną pielgrzymkę do zbawienia u boku Jezusa Chrystusa! [...] jestem wyznania prawosławnego, byłem wychowywany bez Boga, bez wiary, tak jak to było przyjęte 
w „normalnych” rodzinach mieszkających w Związku Radzieckim. Zaprawdę - dziwne są drogi, którymi dociera do nas Jezus Chrystus. Dla mnie szczególnie dziwne, ale jednocześnie pocieszające i budujące jest to, że On wypatrzył mnie w obcym kraju, wśród takich samych przestępców jak ja, prawosławnego wśród katolików - i po prostu poprowadził za sobą! Wystarczyło zobaczyć Go obok siebie, a „zaraziłem się” dobrocią, którą jest On sam! Osobą, która wskazała mi, że Jezus stoi obok mnie, był kapłan katolicki - kapelan ZK. Tak - nie pomyliłem się - dobroć jest „zaraźliwa”, a namacalnie i nadzwyczaj wyraźnie zobaczyłem i poczułem, to pielgrzymując do tronu Matki Bożej Częstochowskiej z Elbląską Pieszą Pielgrzymką. Już trzy lata z rzędu ofiarowuję swój trud, swój ból, swoją radość i swój smutek Jezusowi Chrystusowi i Jego Matce na przebłaganie za grzechy moje i na dziękczynienie za to, co mi uczynił! Po raz pierwszy idąc pielgrzymkowym szlakiem na Jasną Górę, miałem całą burzę uczuć i emocji, których nie sposób opisać. Dominującym uczuciem była miłość, miłość gospodarzy, którzy przyjmowali nas na obiad, nocleg, użyczali swoich domostw i otwierali swe serca. Po miłości następowała radość - radość, z którą zapłakani i obolali pielgrzymi ofiarowali swoje trudy Panu Bogu, a życzliwość i łyk wody - obok idącym - „,bratu” czy „siostrze”. Już od dawna nie mam złudzeń i doskonale wiem, jakie panują nastroje społeczne oraz jaki jest stosunek ludzi do osób skazanych na karę więzienia. Po części też to rozumiem. Z tego właśnie powodu nie oczekiwałem absolutnie niczego, co mogłoby zburzyć mój schemacik ludzkich postępowań i zachowań. Stało się zupełnie inaczej! Mój skrzętnie ułożony model rozpadł się na drobne części za sprawą dobroci ludzkiej, ale stało się też jeszcze coś - ludzie okazujący mi serce i po czasie dowiadujący się, ze jestem więźniem na przepustce mówili mi prawie to samo, co ja czułem! Mówili, że runął ich przez lata „malowany” wizerunek więźnia. Upadkom naszych stereotypów czasami towarzyszyły zabawne sytuacje, oto jedna z nich. Do jednego z nas [...] w trakcie marszu podchodzi pątniczka i mówi ściszonym głosem: „[...] czy wie brat, że z nami idą więźniowie?”, na co ten odpowiedział, że nie zna się na „tych sprawach”. Pątniczka nie ustawała i wskazując na czterech „chłopaków” ubranych na czarno i o długich włosach mówiła: „[...] to chyba oni, posłucha brat, jak przeklinają”. Wspomniane „chłopaki” wykruszyli się z pielgrzymki po kilku dniach, natomiast trzeba było widzieć zdziwienie w oczach owej pątniczki, która od samego początku pielgrzymki obrała sobie na rozmówcę jednego ze skazanych - nawet tego nie podejrzewając. Później zaprzyjaźniliśmy się z ową pątniczką i z wieloma innymi ludźmi, z którymi nam przyszło przemierzyć szlak pielgrzymkowy. Niejednokrotnie podczas pielgrzymowania (jak też po pielgrzymce) spotkałem się ze stwierdzeniem, że pielgrzymka jest swoistym generatorem ładującym człowieka wiarą w Boga, wiarą w dobroć ludzi, ładującym samą dobrocią i miłością do bliźniego. Zgadzam się z tą opinią całkowicie, ponieważ sam tego doświadczyłem, ponieważ sam tym się „zaraziłem”! W więzieniu bardzo rzadko można spotkać 
dobrego człowieka, ale jeszcze rzadziej spotyka się bezinteresowne i dobre czyny. W takim miejscu dobroć jest uważana za przejaw słabości i dlatego, po latach spędzonych w zamknięciu, ludzie odzwyczajają się od niej. Ja też nie byłem wyjątkiem, chociaż doświadczałem przejawów bezinteresownej dobroci ze strony wolontariuszy [...] ze strony ks. kapelana, etc. Niemniej ta dobroć, której doświadczyłem na szlaku pielgrzymkowym, była inna, ona biła niczym młotem, biła w moją zatwardziałą skorupę, rozbijając ją w drobny mak, odsłaniając najlepsze zakamarki mojego jestestwa i co wieczór, na Apelu Jasnogórskim, wyciskając ze mnie łzy, łzy żalu za grzechy, łzy radości i łzy podzięki za to, że dane było mi poznać moc dobroci Bożej i ludzkiej! Zapytany przez naszego kapelana więziennego [...], czy nie chciałbym przed naszą [...] grupą pielgrzymkową podzielić się doświadczeniami swego życia i wiary - zgodziłem się po chwili namysłu. Niczego nie oczekiwałem od tego świadectwa, ale to, co otrzymałem - zupełnie mnie zaskoczyło. Ludzie mnie nie potępiali - potępiając zło, którego się dopuściłem, ludzie mi dziękowali - ubolewając nad nieszczęściem, którego byłem przyczyną, ludzie za mnie się modlili i prosili o modlitwę! Wróciłem do więzienia „zarażony” dobrem, wróciłem pełen wiary i nadziei, a za rok znów wędrowałem polami, lasami, ulicami miast i wiosek do Matki Bożej Częstochowskiej. Podczas swojej drugiej pielgrzymki na Jasną Górę mówiłem świadectwo prawie we wszystkich grupach [...] pielgrzymki. Efekt był zwielokrotnieniem tego sprzed roku i nadzwyczaj wyraźnie pokazał, że nie ma takiego bagna, z którego nie obmyłaby nas Krew Pana Jezusa, trzeba tylko wyciągnąć do Niego rękę, a zawsze otrzymamy oparcie i pomoc. Takie oparcie dostaję teraz, korespondując z wieloma pielgrzymami, przyjaźniąc się z nimi, spotykając się na przepustkach. Rok kolejny i trzecia moja pielgrzymka na Jasną Górę [...], na którą wyruszyłem z więzienia - lecz tym razem wyruszyłem, wypełniając funkcję porządkowego grupy. Na początku wzbraniałem się przed pełnieniem owego zadania, ale z czasem stwierdziłem, że muszę go wykonać i to wykonać jak najlepiej. Nie mogłem zawieść pokładanych we mnie nadziei, bo przeczcież byłem odpowiedzialny za bezpieczeństwo 120 osób i porządek w grupie podczas marszu. I chociaż nie pomodliłem się, tak jak sobie to zaplanowałem zgodnie z doświadczeniami z lat poprzednich, to jednak doświadczyłem głębokiego przekonania, że nie jestem człowiekiem straconym - ani dla ludzi, ani dla Boga! Gospodarzom przyjmującym nas na nocleg, ofiarującym jedzenie, picie i wypoczynek, dającym pieniądze na ofiarę (aby je zanieść do klasztoru na Jasnej Górze) nie sprawiało różnicy, czy jesteśmy klerykami, czy więźniami. Dla nich byliśmy ludźmi idącymi do Matki Bożej i niosącymi ze sobą Wiarę. W oczach Pana Boga nie jestem niczym, mimo że zabiłem człowieka - On powierzył mi życie i bezpieczeństwo 120 osób, bo zwróciłem się do Niego, bo zapragnąłem Miłości i Dobroci! Z różnymi intencjami i prośbami szedłem na każdą kolejną pielgrzymkę, ale nigdy nie otrzymałem tego, o co prosiłem, lecz zawsze otrzymałem to, czego najbardziej potrzebowałem! Już teraz martwię się, 
że kiedyś po opuszczeniu ZK nie będę mógł więcej pielgrzymować na Jasną Górę, bo zostanę wydalony z Polski. Ale wszystkie zmartwienia znikają, kiedy przedstawiam je Panu Bogu, kiedy zaufam Mu, kiedy znów „zarażę” się Jego Dobrocią! (Imię osoby dającej to świadectwo znane autorowi artykułu).

Oto kolejny, obszerny fragment świadectwa dwudziestojednoletniego osadzonego, pt. „Moje przeżycia z Pielgrzymki”.

Zacznę od tego, że szedłem na pielgrzymkę z nadzieją przeżycia głębokich doznań duchowych. Oprócz tego chciałem się pomodlić za moich bliskich, ale miała to być swojego rodzaju pokuta za grzechy. Pierwsze co mnie uderzyło, to ogromna życzliwość ludzka, której nie miałem okazji zbyt często doświadczać. Poza tym był to mój pierwszy od prawie czterech lat kontakt $\mathrm{z}$ wolnością. Ci wszyscy ludzie, uśmiechający się i życzliwi na każdym kroku, to wszystko jest naprawdę piękne! Na pielgrzymce są, wiadomo, chwile lepsze i gorsze, ale intensywność tych lepszych pozwala zapomnieć o gorszych. Do lepszych momentów zaliczam zdecydowanie pewien dzień. Był to już któryś z kolei dzień pielgrzymki, pod koniec dnia, gdy strasznie bolały mnie nogi i odechciewało mi się w ogóle całej pielgrzymki. Zebrałem myśli i pomyślałem, że cały ten ból, i całe zmęczenie, oddaję Jezusowi, bo przecież to wszystko dla Niego (było to na zasadzie rozmowy z Jezusem). W tej właśnie chwili zaufałem Mu w całości, powierzając Mu to wszystko wiedziałem, że jest i będzie jak On zechce, bo jest moim Panem i najlepiej wie, co dla mnie dobre. Przez jakiś czas szedłem i w myślach rozmawiałem z Jezusem. Poczułem nagłe uniesienie, jakby ktoś wziął mnie pod rękę, cały ból i zmęczenie jakby nagle znikły. Szło mi się tak lekko, jakbym w ogóle nie przeszedł tych wszystkich kilometrów. Po kilkunastu minutach ból i zmęczenie wróciły, ale szedłem już spokojnie, bo wiedziałem, że Pan jest przy mnie, a na ból i wszystko, co mi dokuczało, nie zwracałem już uwagi. Muszę się przyznać do rzeczy, która mnie strasznie dobiła $\mathrm{w}$ trakcie pielgrzymki. Po kilku dniach pielgrzymki dopadła mnie dolegliwość niezależna ode mnie. Miałem podejrzenie przepukliny, przez co cztery dni nie mogłem iść. Musiałem jechać. Podczas tych dni, gdy nie szedłem, męczyłem się strasznie (psychicznie). Miałem chwile zwątpienia, bo myślałem, że już wcale nie będę mógł iść. Diagnoza lekarza, który oznajmił, że prawdopodobna będzie operacja, jeszcze bardziej mnie zdołowała. W tych trudnych chwilach ratowała mnie myśl, że taka jest właśnie wola Boska. Na szczęście wolą Boską było też to, że ta rzekoma przepuklina minęła, przez co mogłem znowu iść. Po tym, jak cztery dni jechałem, te następne dni, gdy mogłem wreszcie iść, były dla mnie tym bardziej cenne. Kolejna, piękna dla mnie chwila z pielgrzymki. Pewnego dnia na wieczornej mszy, gdy w kościele było bardzo dużo ludzi. Siedziałem w ławce i nie miałem siły nawet myśleć, taki byłem zmęczony! Pod koniec mszy zawsze śpiewaliśmy tzw. Apel 
Jasnogórski do Matki Bożej. Gdy tego dnia wszyscy wstaliśmy i trzymając się za ręce zaczęliśmy śpiewać, zamknąłem oczy. Zobaczyłem tę całą sytuację jakby z boku. Gdy patrzyłem na tych wszystkich śpiewających ludzi, czułem wielką siłę, która z nich płynęła, a ponad tym wszystkim [...] zobaczyłem Jezusa siedzącego na kamieniu. Bił od Niego wielki spokój, a na Jego twarzy był widoczny uśmiech. To było dla mnie takie mocne, że ze wzruszenia poleciały mi łzy. Przeżycia takie jak to są naprawdę wielką ucztą dla duszy. Myślę, że teraz, nawet gdy wyjdę z więzienia, będę co roku chodził na pielgrzymki. Bo przeżycia na takiej pielgrzymce zapewniają spokój ducha na całe życie, a na pewno na cały rok. Ja już się nie mogę doczekać przyszłorocznej! Nie wspomniałem o tym, ale jeszcze jedną piękną rzeczą podczas pielgrzymki jest to, jak ludzie przyjmują pielgrzymów do swoich domów. Gdy po całym dniu pielgrzym jest strasznie zmęczony i głodny, myśli tylko o tym, aby się najeść, umyć i dobrze wyspać. A Ci ludzie (niekiedy nawet bardzo biedni!) czekają z otwartymi ramionami. [...] na pielgrzymce poznałem wielu fajnych ludzi. Z niektórymi utrzymuję nadal kontakt, a z niektórymi się nawet zaprzyjaźniłem. Ogólnie rzecz biorąc, pielgrzymka na Jasną Górę jest najlepszą rzeczą, jaka mnie do tej pory w życiu spotkała! (Imię dającego świadectwo znane autorowi artykułu) ${ }^{3}$.

Mamy także przypadki osadzonych i byłych skazanych, którzy po jakimś czasie powrócili do zachowań negatywnych, mimo że udział w pielgrzymce zainicjował w ich postawach bardzo pozytywne relacje ludzkie.

Istotną częścią realizowanych zadań w duszpasterstwie więziennym, stąd wartą publikacji, jest udział przedstawicieli naszego duszpasterstwa w pracach międzynarodowych. Obecnie aktywnie uczestniczymy w dwóch organizacjach: International Commision of Prison Catholic Chaplains (ICPCC), od 2002 roku istnieje także ICPPC dla poszczególnych kontynentów, tak więc pracujemy w ICPCC-Europe. Jako naczelny kapelan polskiego więziennictwa zostałem zaproszony do zarządu ICPCC-Europe, z obowiązkiem koordynacji prac duszpasterstw więziennych w Europie Środkowej i Wschodniej, oraz Prison Fellowship International (PFI), która jest międzynarodowym stowarzyszeniem świeckich wolontariuszy duszpasterstw więziennych. Jest to organizacja zajmująca się

${ }^{3}$ Osobnym dziełem duszpasterstwa więziennictwa jest organizowana od kilku lat doroczna autokarowa pielgrzymka pracowników więziennictwa i ich rodzin na Jasną Górę. W ten sposób dołączyliśmy do wielu profesji, które regularnie pielgrzymują wedle polskiej tradycji do Częstochowy. Do tych pielgrzymek czasami włączamy także małe grupki więźniów (w ramach przepustek, urlopów), jadących wraz z wolontariuszami. Popularność pielgrzymki systematycznie wzrasta. Drukowane są materiały zawierające wspomnienia pielgrzymkowe, treści homilii, Dróg Krzyżowych i wykładów. Osobnym zagadnieniem są organizowane dla pracowników resortu pielgrzymki zagraniczne połączone ze zwiedzaniem i odpoczynkiem. 
promocją i profesjonalizacją świeckich pomocników kapelanów więziennych ${ }^{4}$. Istnieje jeszcze europejska i światowa komisja ekumeniczna dla kapelanów (IPCA), w której prace także się włączamy.

Osobne zagadnienie, któremu poświęcona jest już literatura, to praca ludzi świeckich w ramach duszpasterstwa więziennego, która może być znakomitym przykładem tego, jak organizować współpracę duchownych i świeckich w ewangelizacji. Nasze duszpasterstwo współorganizowało liczne zjazdy dla świeckich wolontariuszy w Polsce, a także brało udział w wielu zjazdach i szkoleniach organizowanych przez PFI na całym świecie ${ }^{5}$.

\section{BIBLIOGRAFIA}

Danielou, J., Marrou, H.I. (1984). Historia Kościoła (t. 1). Warszawa: Instytut Wydawniczy PAX. Morawiec, M. (2000). O filozoficznym pojęciu sensu życia ludzkiego. W: P. Mazanka (red.), Filozoficzne orientacje w wyborze życia. Warszawa: Wydawnictwo UKSW.

Pierzchala, K. (2013). Kapelan więzienny w procesie resocjalizacji penitencjarnej. Toruń: Wydawnictwo Adam Marszałek.

Pierzchąa, K. (2015a). Skazani ale nie potepieni. Wyd. II rozszerzone. Toruń: Wydawnictwo Adam Marszałek.

Pierzchala, K. (2015b). The Process of Social Reintegration of Convicts on the Background of World Penitentiary System. The Analytical and Synthetic Outline of the Issue [Proces readaptacji społecznej skazanych na tle światowego systemu penitencjarnego. Zarys analityczno-syntetyczny zagadnienia]. Polskie Towarzystwo Nauk Politycznych i Polska Akademia Nauk. Polish Political Science. Yearbook, 44, 154-170.

Pierzchala, K. (2016). Destygmatyzacja przestępców w świetle Magisterium Kościoła oraz poglądów na resocjalizację. Kraków: Oficyna Wydawnicza „Impuls”.

PierzchaŁa, K. (2017). Pedagogical and Theological Reflections on the De-Stigmatization Process, [Refleksje pedagogiczno-teologiczne nad procesem destygmatyzacji]. Polish Journal of Social Rehabilitation (Resocjalizacja Polska), 13, 17-37.

Pierzchala, K., Cekiera, Cz. (2008). Zwalczanie patologii społecznych w systemie penitencjarnym Polski i USA. Toruń: Wydawnictwo Adam Marszałek.

Pierzchala, K., Cekiera, Cz. (2009). Człowiek a patologie społeczne. Toruń: Wydawnictwo Adam Marszałek.

\footnotetext{
${ }^{4}$ Ks. Sikorski pracował w zarządach tych organizacji jako odpowiedzialny za kraje środkowej i wschodniej Europy. Ta potrzeba koordynacji duszpasterstw na terenie naszej części Europy przez polskiego naczelnego kapelana - można powiedzieć - nabrała cech tradycji. Warto także wspomnieć, że we wrześniu 1996 roku Polska była gospodarzem zjazdu kapelanów z 50 krajów zrzeszonych w ICPCC.

${ }^{5} \mathrm{~W}$ celu doskonalenia umiejętności posługiwania przez świeckich w zakładach penitencjarnych powołaliśmy w duszpasterstwie więziennym Bractwo Więzienne, które zrzeszone jest w federacji Prison Fellowship International.
} 
Pismo Święte Starego i Nowego Testamentu (1980). Poznań-Warszawa: Pallottinum.

Podsiad, A., Więckowski, Z. (1983). Mały słownik terminów i pojęć filozoficznych. Warszawa.

Romaniuk, K. (1985). Konkordancja do Pisma Świętego Nowego Testamentu. Warszawa: Wydawnictwo ATK.

Wojtas, P. (2006). Wywiad do audycji „Nie tylko z ambony” w Programie I Polskiego Radia.

W: Abp L.S. GŁóDź (red.), Nie tylko z ambony. Audycje w Programie I Polskiego Radia

- 2005. Warszawa: Wydawnictwo Diecezji Warszawsko-Praskiej.

Wojtas, P. (2007). Duszpasterstwo więzienne w pracy penitencjarnej. W: J. ŚWitKa, M. KuĆ (red.), Duszpasterstwo więzienne w pracy penitencjarnej. Lublin: Wydawnictwo KUL.

Wojtas, P., Pierzchąa, K. (2015). Duszpasterstwo więzienne w Polsce. W: T. Bulenda, A. Rzepliński (red.), Modernizowanie więziennictwa. V Kongres Penitencjarny (s. 475496). Warszawa: Uniwersytet Warszawski Instytut Profilaktyki Społecznej i Resocjalizacji, Centralny Zarząd Służby Więziennej.

Zdybicka, Z.J. (1977). Człowiek i religia. Zarys filozofii religii. Lublin: Wydawnictwo KUL.

\section{DUSZPASTERSKA POMOC W SPOŁECZNEJ READAPTACJI OSOBOM PRZEBYWAJĄCYM W JEDNOSTKACH PENITENCJARNYCH}

\section{Streszczenie}

Biblijne źródła duszpasterstwa więziennego jako podstawa do pracy z człowiekiem izolowanym w więzieniu przynoszą potrzebę właściwej pracy penitencjarnej. Artykuł prezentuje krótkie omówienie pracy duszpasterstwa więziennego w ostatnich stu latach oraz po $1990 \mathrm{r}$. głównie analizując to, jak ono rozwija się obecnie poprzez różne formy naprawiania i budowania relacji interpersonalnych. Przytoczone świadectwa więźniów świadczą o tym, że duszpasterstwo więzienne przyniosło pomoc w przemianie ich życia.

Słowa kluczowe: więzienie w Biblii; duszpasterstwo więzienne; kapelan więzienny; penitencjarystyczna resocjalizacja; praktyki religijne.

\section{MINISTRATION HELP IN SOCIAL AND PERSONAL REHABILITATION FOR PRISONERS}

\section{Summary}

Biblical sources of prison chaplaincy work with prisoners help prisoners to start own work to change life in proper way. A short history of prison chaplaincy after 1990 and how it is developing now. Personal testimony of prisoners whom prison chaplaincy had helped to start to run a new and proper life.

Key words: prison in the Bible; prison priesthood; prison chaplain; penitentiary resocialization; religious practices. 